\title{
Editorial
}

\section{Political Parties' Programmes: Examples of Governance against Human Rights?}

\author{
Aurelia Colombi Ciacchi \\ Editor-in-Chief EJCL; Professor of Law and Governance, \\ University of Groningen \\ A.L.B.Colombi.Ciacchi@rug.nl
}

Even in the oldest and most stable Western European democracies such as in the UK and the Netherlands, some political parties seem to view international human rights as one of their fiercest enemies. Two contributions in a previous issue of EJCL ${ }^{1}$ already mentioned the 2015 Manifesto of the British Conservative Party, which plans to scrap the Human Rights Act and replace it with a British Bill of Rights. Through the scrapping of the Human Rights Act, the Conservative Party explicitly intends to "break the formal link between British courts and the European Court of Human Rights", and make the U K Supreme Court "the ultimate arbiter of human rights matters" in the country. ${ }^{2}$

The planned scrapping of the Human Rights Act is now put on hold until the Brexit arrangements are confirmed. On 24 January 2017, in the House of Commons, Justice Minister Sir Oliver Heald said: "We are committed to

1 J. Husa, 'Human Rights? No Thanks We're English! Anti-Convergence Thesis Revisited', European Journal of Comparative Law and Governance Vol. 3 (2016), 229 and A. Colombi Ciacchi, 'Brexit and the Anti-Convergence Thesis' (Editorial), ibid., 225.

2 Conservative Party Manifesto, 2015, 6o. Retrieved 21 April 2017, https://www.conservatives .com/Manifesto. On this Manifesto as well as on the strained relationship between the UK and European human rights in general, see inter alia C. Gearty, On Fantasy Island: Britain, Europe, and Human Rights (Oxford University Press, 2016); and the contributions included in K.S. Ziegler, E. Wicks and L. Hodson (eds), The UK and European Human Rights: A Strained Relationship? (Oxford: Hart Publishing, 2015).

(C) CIACCHI, 2017 | DOI 10.1163/22134514-00402004

This is an open access article distributed under the terms of the prevailing CC-BY-NC license at the time of publication. 
reforming our domestic human rights framework and we will return to our proposals once we know the arrangements for our exit from the European Union." He added it would take some time before a meeting is held with the Scottish justice minister to discuss repealing the Human Rights Act north of the border, as the government was prioritising Brexit. "I think it important for us to sort out the $\mathrm{EU}$ side of matters and the exit from the $\mathrm{EU}$ before we return to that subject," he said. ${ }^{3}$

The Government's plans to scrap the Human Rights Act have thus been shelved until after Brexit. Some commentators report that according to some sources, Theresa May is preparing to abandon the plans for a British Bill of Rights entirely, because Brexit will significantly strengthen the sovereignty of British courts. $^{4}$

This allegation, however, does not seem to match with previous statements of Theresa May according to which the independence of British courts from the ECtHR cannot be achieved through Brexit: the UK would need to withdraw from the ECHR. Indeed, Theresa May has been absolutely clear she does want to leave the Convention. In a speech of 25 April 2016, she said: "The ECHR can bind the hands of Parliament, adds nothing to our prosperity, makes us less secure by preventing the deportation of dangerous foreign nationals - and does nothing to change the attitude of governments like Russia's when it comes to human rights. So regardless of the EU referendum, my view is this. If we want to reform human rights law in this country, it isn't the EU we should leave but the ECHR and the jurisdiction of its court."

3 'Will the Human Rights Act be Scrapped?'. The Week (theweek.co.uk), 25 January 2017. Retrieved on 21 April 2017, http://www.theweek.co.uk/63635/will-the-human-rights-act-be -scrapped.

4 S. Swindford, 'Theresa May is preparing to abandon plans for a British Bill of Rights, sources suggest'. The Telegraph (telegraph.co.uk), 26 January 2017. Retrieved 24 April 2017, http:// www.telegraph.co.uk/news/2017/01/26/theresa-may-preparing-abandon-plans-british-bill -rights-sources/.

5 Home Secretary's speech on the UK, EU and our place in the world, from: Home Office and the Rt Hon Theresa May MP, 25 April 2016. Retrieved 21 April 2017, https:/www.gov.uk/ government/speeches/home-secretarys-speech-on-the-uk-eu-and-our-place-in-the-world. Teresa May's position is sharply criticized by Charles Falconer, who points out that "(t)he prime minister is wrong on every point (...), the Human Rights Act explicitly preserves parliamentary sovereignty (...); membership of the convention adds to UK prosperity (...); preventing the deportation of foreign terrorists because of what they may face on their return has not reduced our security, failing to stop homegrown Isis supporters going abroad and then returning to the UK is the much bigger threat to our security; and (...) if the UK leaves the convention that would be a green light for Russia to ignore any Strasbourg ruling it chose." See C. Falconer, 'Human rights are under threat - just when we need them most'. The Guardian 
At present, the Conservative Party does not have a sufficient majority to leave the ECHR. In December 2016, Theresa May announced she would "campaign to leave the European Convention on Human Rights in 2020 election". 6 Then however, in April 2017, in a suprise move, she called a general election on 8 June. Obviously, the Tories want to grasp the chance to obtain a much larger majority in Parliament, since the mid April 2017 polls predict for them a 200 seat lead over Labour. ${ }^{7}$

The first priority of the Conservative Party is to make a success out of Brexit. The Government is aware that it would not be wise to do two big constitutional reforms - Brexit and the scrapping of the Human Rights Act - at the same time. ${ }^{8}$ After having finalized Brexit, however, Theresa May is expected to pursue her plans to scrap the Human Rights Act and leave the ECHR further. Should the polls prediction become reality, after 8 June there will be a sufficient majority in the UK Parliament not only to conclude the Brexit negotiations more smoothly, but also to leave the ECHR. This could be a disaster for both the $\mathrm{uk}$ and Europe as a whole. ${ }^{9}$

(theguardian.com), 3 January 2017. Retrieved 24 April 2017, https://www.theguardian.com/ commentisfree/2017/jan/o3/european-convention-human-rights-threat.

6 Will Worley, 'Theresa May 'will campaign to leave the European Convention on Human Rights in 2020 election". The Independent (independent.co.uk), 29 December 2017. Retrieved on 21 April 2017, http://www.independent.co.uk/news/uk/politics/theresa-may-campaign-leave -european-convention-on-human-rights-2020-general-election-brexit-a7499951.html.

7 A. Kirk and P. Scott, 'Theresa May could give the Conservatives a 200 seats lead over Labour in an early General Election'. The Telegraph (telegraph.co.uk), 18 April 2017. Retrieved on 24 April 2017, http://www.telegraph.co.uk/news/2017/04/18/theresa-may-could-give -conservatives-200-seat-lead-labour-early/.

8 The Justice Secretary Liz Truss said: "Given that we are leaving the European Union and we will have the Great Repeal Bill going through Parliament, clearly that is going to signify a major constitutional change. (...) (T)he British Bill of Rights, whilst it remains a commitment, is not something we can do at the same time as we are putting through that Great Repeal Bill. (...)That is going to affect the constitution. It's important we only do one constitutional reform at a time." See J. Stone, 'British Bill of Rights plans shelved again for several more years, Justice Secretary confirms'. The Independent (independent.co.uk), 23 February 2017. Retrieved on 24 April 2017, http://www.independent.co.uk/news/uk/politics/scrap-human -rights-act-british-bill-of-rights-brexit-liz-truss-theresa-may-a7595336.html.

9 See C. Falconer (n. 5): "it will be a green light for despots and a disaster for ordinary people". Already in January 2014, the President of the European Court of Human Rights, Judge Dean Spielmann, said in an interview that it would be a "political disaster" if Britain left the European Convention on Human Rights. See ввс News, 14 January 2014. Retrieved on 24 April 2017, http://www.bbc.com/news/uk-politics-25729321. For an academic analysis of the disadvantages of both Brexit and a withdrawal of the UK from the ECHR see i.a. T. Lock, T.G. Daly, E. Bates, C. Bell, K. Dzehtsiaroy, D. Edward, M. Hunt, K. Dimitrios, F. De Londras, 
The British Conservative Party is not the sole political party in Europe who aims at reducing the impact of the ECHR and the ECtHR case law on national law. In the Netherlands, considerable limitations of the impact of international human rights on national law are currently planned by the People's Party for Freedom and Democracy (Volkspartij voor Vrijheid en Democratie, VVD), led by the acting Prime Minister Mark Rutte, who won the last three general elections in June 2010, September 2012, and March 2017. According to its 2017-2021 Election Programme, ${ }^{10}$ the VVD intends to scrap the direct effect of international treaties and decisions of international organisations on Dutch law, ${ }^{11}$ and reduce the interpretative leeway of courts for what concerns international law - and human rights law in particular. ${ }^{12}$

The Dutch Bar (Nederlandse Orde van Advocaten) has sharply criticized these VvD plans. The Report of the Dutch Bar's Commission on the Rule of Law in Election Programmes ${ }^{13}$ (hereafter: "the Report") analysed the 2017 election programmes of 13 Dutch political parties. It used three colors - green, orange, and red - to differentiate the plans that could improve the rule of law (marked in green) from the plans that could weaken the rule of law (marked in orange), and the plans clearly in conflict with the rule of law (marked in red). ${ }^{14}$ The Report marked two plans of the VVD in red: on the one hand, the plans to change both the international and the national law so as to allow to make Dutch citizens, who join a terroristic organisation, stateless; ${ }^{15}$ and on the other hand, the abovementioned plans to scrap the direct effect of international treaties and

C. Mac Amhlaigh, C. McCrudden, and A. Smith, 'Brexit and the British Bill of Rights' (February 6, 2017). Retrieved on 24 April 2017, https://ssrn.com/abstract=2913566.

'Zeker Nederland - vvD verkiezingsprogramma 2017-2021', 9 December 2016. Retrieved on 24 April 2017, https://vvd.nl/content/uploads/2016/11/vvd_verkiezingsprogramma_pages .pdf.

11 Ibid, 23: "De directe doorwerking van ieder verbindende bepaling van verdragen en van besluiten van volkenrechtelijke organisaties moet worden afgeschaft".

12 Ibid, 23: "minder interpretatie door rechters nodig".

13 Nederlandse Orde van Advocaten, 'De rechtsstaat: een quick scan. De partijprogramma's voor de verkiezing 2017 - rechtsstaatelijk? Rapport van de Commissie Rechtsstaatelijkheid in Verkiezingsprogramma's', The Hague, 14 February 2017. Until mid March 2017, the report was available on the Dutch Bar's website (https://www.advocatenorde.nl/nieuws/ verkiezingsprogrammas-op-gespannen-voet-met-de-rechtsstaat). At present, the Report does not seem to available at the website of the Dutch Bar any longer. However, it is still available at other websites, i.a. HP De Tijd: http://www.hpdetijd.nl/2017-02-14/aanval-op -rechtsstaat/. Retrieved on 24 April 2017, https://www.scribd.com/document/339286916/ Commissie-rechtsstatelijkheid-in-verkiezingsprogramma-s-2017\#.

14 For an explanation of the use of the three colors see ibid., 6.

15 'Zeker Nederland - vVD verkiezingsprogramma 2017-2021' (n 10) 14. 
decisions of international organisations, and reduce the interpretative leeway of courts. ${ }^{16}$ The Report denounces that the latter proposal entails "a strong infringement of the protection of fundamental rights in the Netherlands as it is currently guaranteed by international treaties and independent Dutch and European courts". ${ }^{17}$

An even sharper criticism is raised by Professor Wouter Veraart from the vu University Amsterdam. He can hardly believe that the largest government party in the Netherlands could formulate such plans. "If this breaks through, one will no longer be able to invoke human rights before Dutch courts. Without adequate protection of fundamental rights, we find that a country no longer respects the rule of law. They want to withdraw from international treaties because these stand in the way of their immigration policy. This comes very close to what happens in America with Trump (...)."18

I fully agree with Veraart. Such examples of political governance against international human rights can usually be found in election programmes of far-right populist parties. ${ }^{19}$ That such plans are now pursued by the most voted political parties in the U K and the Netherlands, is a very worring sign.

16 Ibid., 23.

17 Nederlandse Orde van Advocaten, 'De rechtsstaat: een quick scan' (n 13) 30.

18 See the interview with Prof. Veraart published by A. Kas, 'Hoogleraar rechtsfilosofie: 'Politici brengen rechtsstaat in gevaar", NRC (nrc.nl), 14 February 2017. Retrieved on 24 April 2017, https://www.nrc.nl/nieuws/2017/02/14/politici-brengen-rechtsstaat-in-gevaar -667416o-a1545915: "Wat me ook aangrijpt is wat de VvD wil: die stelt voor om de directe werking van internationale verdragen, waar ook mensenrechten bij horen, uit de Nederlandse rechtsorde te halen. Het is toch onwaarschijnlijk dat de grootste regeringspartij zoiets voorstelt? Als dit doorgaat, kun je voor de Nederlandse rechter geen beroep meer op die mensenrechten doen. Zonder adequate bescherming van fundamentele rechten vinden wij een land niet meer rechtsstatelijk. Ze willen die verdragen opzeggen omdat ze in de weg zitten bij hun immigratiebeleid. Dit komt heel dicht in de buurt bij wat je in Amerika met Trump ziet gebeuren: hij voelt zich gehinderd bij het uitvoeren van zijn decreten."

19 See e.g. in the Netherlands the 2017 election programme of Geert Wilder's Party for Freedom (Partij voor de Vrijheid, Pvv), available at https://www.pvv.nl/visie.html (Retrieved 24 April 2017). In Switzerland, on 10 March 2015, the right-wing Swiss People Party, SVP (Schweizerische Volkspartei) officially launched the collection of signatures for their referendum initiative against international law. Luckily, most other political parties in Switzerland - the Liberal Democratic Party, the Social Democratic Party, the Christian Democratic People's Party, the Green Party, the Green Liberal Party, the Conservative Democratic Party and the Evangelical People's Party - reacted with a joint press statement against the SVP initiative. See Information Platform humanrights.ch, 11 March 2015. Retrieved on 24 April 2017, http://www.humanrights.ch/en/switzerland/internal-affairs/ law/rights-swiss-peoples-party-initiative. 